\title{
WestVirginiaUniversity
}

THE RESEARCH REPOSITORY @ WVU

Volume 45 | Issue 2

Article 18

February 1939

\section{Trade Associations in Law and Business}

Julius Cohen

West Virginia University

Follow this and additional works at: https://researchrepository.wvu.edu/wvlr

Part of the Labor and Employment Law Commons

\section{Recommended Citation}

Julius Cohen, Trade Associations in Law and Business, 45 W. Va. L. Rev. (1939).

Available at: https://researchrepository.wvu.edu/wvlr/vol45/iss2/18

This Book Review is brought to you for free and open access by the WVU College of Law at The Research Repository @ WVU. It has been accepted for inclusion in West Virginia Law Review by an authorized editor of The Research Repository @ WVU. For more information, please contact ian.harmon@mail.wvu.edu. 
that they do so. Yet when circumstances permitted they were not unwilling to hide behind Woodrow Wilson's coat tails in denying that the Treaty of London was any longer applicable. This book will do much to help place Italian policy at the Versailles Conference in its true light. In doing so it will also shed some new light upon Allied policy and will aid in explaining the strained relations between Italy and Great Britain and France since that time. Even though the recent Munich Pact was not an Italian vietory in any sense Mussolini must have received some pleasure out of the fact that Great Britain and France found themselves in an awkward position before Hitler and were compelled to accept a loser's terms.

An important feature of this volume is the more than two hundred pages of pertinent documents covering the period from 1915 to 1919. There are also an adequate bibliography and an excellent index.

West Virginia University,

Carl m. Frasure.

Morgantown, West Virginia.

Trade Associations in Latw and Busnness. By Benjamin S. Kirsh and Harold Roland Shapiro. New York. Central Book Company, 1938. Pp. 399.

In 1912, one year after the Supreme Court distilled the "rule of reason" out of the Sherman Anti-Trust Act, A. J. Eddy presented a forceful apologia for "cooperative competition," a term used to describe the trade association device which he sponsored. This year another apologia has appeared in print. Needless to say the sledding is much easier. The authors have behind them the fruition of a long struggle in which the courts have already carved out a comfortable niche for the trade association. The present work, however, is a theme on a variation from Eddy's. Whereas Eddy sought to provide an impetus for an incipient trade association movement, Messrs. Kirsch and Shapiro face a matured system in an attempt to demareate what is economically desirable and legal from what is economically undesirable and illegal.

On the economic level, the tone of the book is Brandeisian. The authors sponsor an intelligent cooperation on the part of competitors, a cooperation which offers the advantages of large scale

1 FDDY, ThE NeT CoMpetimion (1912). 
consolidation and yet preserves individual initiative and independence. ${ }^{2}$ Thus the view that such trade association activities as statistical reporting, uniform cost accounting, standardization of products, credit bureau functions, etc., offer benefits not only to competitors, but to the public as well.

The course of judicial decisions which they plot presents a somewhat familiar picture - broadly, that when the trade association serves as a medium for the making of agreements to curtail production, regulate price, and apportion profits in order to control the market, it will meet the restraining force of the Sherman Act. They find little logic, however, in the court's reluctance to employ the "rule of reason" in determining the legality of price fixing by trade associations, especially in view of its use in the merger cases, in which the control of price has been achieved by centralized ownership. They view with critical despair the ability of a recalcitrant minority to cling to the protection of the AntiTrust Acts when a majority in a trade association seek to rid an industry of uneconomic practices. Perhaps the Supreme Court's venture into the realm of realistic market economics in the Appalachian case $^{3}$ will revive the hopes of the authors.

A word about the organization of the material. Chapters II to VI contain discussions of the activities of trade associations which, in the main, are sanctioned by the Anti-Trust Acts, e.g., statistical reporting, uniform cost accounting, trade relations, standardization of commodities, credit bureau functions, etc. It is in the chapters headed "Boycotts and Defensive Combinations", "Uniform Basing Point Systems of Trade Associations" and "Collective Purchasing Functions of Trade Associations" that one feels the impact of the Anti-Trust Acts, for basically, they are linked closer to the problem of market control. In the chapter" on "Patent Interchange", the authors describe the apparent inconsistency of two fundamental policies - the policy of monopoly sponsored by the patent statutes, and the poliey of "free" competition sponsored by the Anti-Trust Acts. To them, a patent interchange is "nothing more than a scientific and intelligent co-operation of creative or inventive thought, much akin to a bureau for scientific research." The last chapter on "Foreign Trade Functions of Trade Associ-

2 For a similar view, see the dissent of $\mathrm{Mr}$. Justice Brandeis in American Column \& Lumber Co. จ. United States, 257 U. S. 377,42 S. Ct. 114, 66 I. Id. 284 (1921).

3 Appalachian Coals, Inc. v. United States, 288 U. S. 344, 53 S. Ct. 471, 77 L. Ed. 825 (1933). 
ations" emphasizes the need for exempting groups of exporters from the Anti-Trust Acts in order to compete with industrial and commercial combinations abroad.

Surprisingly lacking in this otherwise able presentation is a consideration of the consumer's position in the light of trade association activities. The authors have written only a sentence on the possibility of monopolistic competition in a market dominated by a few. The theory that a monopolistic position detrimental to the consumer may be reached in the market, even in the absence of agreements condemned by the Anti-Trust Acts, has been widely accepted by economists. ${ }^{5}$ Surely, it would have been in order to consider this phenomenon in weighing the merits and the demerits of the trade association device.

West Virginia University,

Jutus CoHen.

Morgantown, West Virginia.

4 P. 41.

S See, for example, Chamberlin, The Theory of Monopolistjo Competition (1936); RoBinson, The Econonics OF IMPERFECT ConipeTition (1933); Mason, MLonopoly in Law and Economics (1937) 47 YALE L. J. 34. 